\title{
Front Matter: Volume 7418
}

, "Front Matter: Volume 7418," Proc. SPIE 7418, Organic Semiconductors in Sensors and Bioelectronics II, 741801 (17 September 2009); doi: 10.1117/12.846119

Event: SPIE Photonic Devices + Applications, 2009, San Diego, California, SPIE. United States 


\title{
PROCEEDINGS OF SPIE
}

\section{Organic Semiconductors in Sensors and Bioelectronics II}

\author{
Ruth Shinar \\ George G. Malliaras \\ Editors
}

4-6 August 2009

San Diego, California, United States

Sponsored and Published by

SPIE 
The papers included in this volume were part of the technical conference cited on the cover and title page. Papers were selected and subject to review by the editors and conference program committee. Some conference presentations may not be available for publication. The papers published in these proceedings reflect the work and thoughts of the authors and are published herein as submitted. The publisher is not responsible for the validity of the information or for any outcomes resulting from reliance thereon.

Please use the following format to cite material from this book:

Author(s), "Title of Paper," in Organic Semiconductors in Sensors and Bioelectronics II, edited by Ruth Shinar, George G. Malliaras, Proceedings of SPIE Vol. 7418 (SPIE, Bellingham, WA, 2009) Article CID Number.

ISSN 0277-786X

ISBN 9780819477088

Published by

SPIE

P.O. Box 10, Bellingham, Washington 98227-0010 USA

Telephone +1 3606763290 (Pacific Time) · Fax +1 3606471445

SPIE.org

Copyright (C) 2009, Society of Photo-Optical Instrumentation Engineers

Copying of material in this book for internal or personal use, or for the internal or personal use of specific clients, beyond the fair use provisions granted by the U.S. Copyright Law is authorized by SPIE subject to payment of copying fees. The Transactional Reporting Service base fee for this volume is $\$ 18.00$ per article (or portion thereof), which should be paid directly to the Copyright Clearance Center (CCC), 222 Rosewood Drive, Danvers, MA 01923. Payment may also be made electronically through CCC Online at copyright.com. Other copying for republication, resale, advertising or promotion, or any form of systematic or multiple reproduction of any material in this book is prohibited except with permission in writing from the publisher. The CCC fee code is 0277-786X/09/\$18.00.

Printed in the United States of America.

Publication of record for individual papers is online in the SPIE Digital Library.

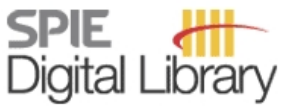

SPIEDigitalLibrary.org

Paper Numbering: Proceedings of SPIE follow an e-First publication model, with papers published first online and then in print and on CD-ROM. Papers are published as they are submitted and meet publication criteria. A unique, consistent, permanent citation identifier (CID) number is assigned to each article at the time of the first publication. Utilization of CIDs allows articles to be fully citable as soon they are published online, and connects the same identifier to all online, print, and electronic versions of the publication. SPIE uses a six-digit CID article numbering system in which:

- The first four digits correspond to the SPIE volume number.

- The last two digits indicate publication order within the volume using a Base 36 numbering system employing both numerals and letters. These two-number sets start with 00, 01, 02, 03, 04, $05,06,07,08,09,0 A, 0 B \ldots 0 Z$, followed by 10-1Z, 20-2Z, etc.

The CID number appears on each page of the manuscript. The complete citation is used on the first page, and an abbreviated version on subsequent pages. Numbers in the index correspond to the last two digits of the six-digit CID number. 


\section{Contents}

$\checkmark$ Conference Committee

vii WISE: the Wide-field Infrared Survey Explorer (Plenary Paper) [7419A-204]

E. L. Wright, Univ. of California, Los Angeles (United States)

\section{SESSION 1 ORGANIC SEMICONDUCTORS IN SENSORS AND BIOELECTRONICS I}

741802 Contrasting responses of organic transistors to nerve gas and explosive simulant vapors (Invited Paper) [7418-01]

H. E. Katz, J. Huang, K. C. See, T. Dawidcyk, The Johns Hopkins Univ. (United States)

741803 Sensing nitroaromatic analytes with a bifluorene-cored dendrimer [7418-02]

H. Cavaye, H. Barcena, P. E. Shaw, P. L. Burn, S.-C. Lo, P. Meredith, The Univ. of Queensland (Australia)

\section{SESSION 2 ORGANIC SEMICONDUCTORS IN SENSORS AND BIOELECTRONICS II}

741806 Luminescent conjugated oligothiophenes: real time in vivo imaging of biomolecules (Invited Paper) [7418-05]

K. P. R. Nilsson, Linköping Univ. (Sweden)

741809 Sniffing out cancer in the breath: detection of non-polar volatile compounds through carrier scattering in random networks of carbon nanotubes (Invited Paper) [7418-08]

H. Haick, P. Gang, U. Tisch, Y. Zilberman, Technion-Israel Institute of Technology (Israel);

W. Pisula, X. Feng, K. Müllen, Max-Planck-Institut für Polymerforschung (Germany)

7418 OA Polymer biophotonic lab-on-chip devices with integrated organic semiconductor lasers (Invited Paper) [7418-09]

T. Mappes, Univ. Karlsruhe (Germany); C. Vannahme, Forschungszentrum Karlsruhe GmbH (Germany) and Univ. Karlsruhe (Germany); S. Klinkhammer, Univ. Karlsruhe (Germany) and Forschungszentrum Karlsruhe (Germany); T. Woggon, M. Schelb, Univ. Karlsruhe (Germany); S. Lenhert, J. Mohr, Forschungszentrum Karlsruhe (Germany); U. Lemmer, Univ. Karlsruhe (Germany)

\section{SESSION 3 ORGANIC SEMICONDUCTORS IN SENSORS AND BIOELECTRONICS III}

7418 OB Novel concepts for organic optical oxygen sensor devices (Invited Paper) [7418-10] S. Sax, A. Neuhold, NanoTecCenter Weiz GmbH (Austria); E. J. W. List, NanoTecCenter Weiz GmbH (Austria) and Graz Univ. of Technology (Austria) 
7418 OD Transient emission in OLEDs: implications for sensing applications [7418-12]

R. Liu, Z. Gan, Y. Cai, lowa State Univ. (United States); A. Smith, Integrated Sensor

Technologies, Inc. (United States); J. Shinar, lowa State Univ. (United States) and Integrated Sensor Technologies, Inc. (United States); R. Shinar, Integrated Sensor Technologies, Inc.

(United States) and lowa State Univ. (United States)

\section{SESSION 4 ORGANIC SEMICONDUCTORS IN SENSORS AND BIOELECTRONICS IV}

7418 OF Polymer-based photodetectors for structurally integrated photoluminescence based oxygen sensors [7418-14]

K. S. Nalwa, lowa State Univ. (United States); Y. Cai, Ames Lab. (United States);

A. L. Thoeming, lowa State Univ (United States); R. Shinar, lowa State Univ. (United States); J. Shinar, Ames Lab. (United States); S. Chaudhary, lowa State Univ. (United States) and Ames Lab. (United States)

\section{SESSION 5 ORGANIC SEMICONDUCTORS IN SENSORS AND BIOELECTRONICS V}

7418 Ol Ultrasensitive solution processed polymer photodetectors [7418-17]

X. Gong, M. Tong, J. S. Moon, A. J. Heeger, Univ. of California, Santa Barbara (United States)

\section{SESSION 6 ORGANIC SEMICONDUCTORS IN SENSORS AND BIOELECTRONICS VI}

$74180 Q \quad$ Large-area stretchable organic transistor integrated circuits for sensor and display applications (Invited Paper) [7418-25]

T. Sekitani, T. Someya, The Univ. of Tokyo (Japan)

\section{POSTER SESSION}

7418 OR OLED-based biosensing platform with ZnO nanoparticles for enzyme immobilization

[7418-26]

Y. Cai, R. Shinar, J. Shinar, Ames Lab. and lowa State Univ. (United States)

Author Index 


\title{
Conference Committee
}

\author{
Symposium Chair \\ Zakya H. Kafafi, National Science Foundation (United States) \\ Conference Chairs \\ Ruth Shinar, lowa State University (United States) \\ George G. Malliaras, Cornell University (United States)
}

Program Committee

Magnus Berggren, Linköpings Universitet (Sweden)

Graciela B. Blanchet, Nano-Terra, Inc. (United States)

Emil J. W. List, Technische Universitaet Graz (Austria)

Roisin Owens, Cornell University (United States)

Franky So, University of Florida (United States)

Luisa Torsi, Università degli Studi di Bari (Italy)

Session Chairs

1 Organic Semiconductors in Sensors and Bioelectronics I

loannis Kymissis, Massachusetts Institute of Technology (United States)

2 Organic Semiconductors in Sensors and Bioelectronics II

Howard E. Katz, The Johns Hopkins University (United States)

3 Organic Semiconductors in Sensors and Bioelectronics III

Fabio Cicoira, Cornell University (United States) and CNF-IFN (Italy)

4 Organic Semiconductors in Sensors and Bioelectronics IV

Emil J. W. List, Technische Universitaet Graz (Austria)

5 Organic Semiconductors in Sensors and Bioelectronics $V$

Paul L. Burn, The University of Queensland (Australia)

6 Organic Semiconductors in Sensors and Bioelectronics VI

Magnus Berggren, Linköping Universitet (Sweden) 
Downloaded From: https://www.spiedigitallibrary.org/conference-proceedings-of-spie on 25 Apr 2023

Terms of Use: https://www.spiedigitallibrary.org/terms-of-use 